\author{
Berika Beridze, Monika Dering \\ Laboratory of Biogeography and Systematics \\ Institute of Dendrology PAS \\ 5 Parkowa Str., 62-035, Kórnik \\ E-mail: berikaberidze@man.poznan.pl \\ mdering@man.poznan.pl
}

\title{
PROBLEMS AND THREATS TO THE CAUCASUS FOREST ECOSYSTEMS ON THE EXAMPLE OF CASTANEA SATIVA
}

\section{THE CAUCASUS: A HOTSPOT OF DIVERSITY}

"The Caucasus ecoregion is one of the most biologically rich and culturally diverse region on Earth," according to the World Wildlife Fund (www.panda.org). Indeed, this small area, about the size of Spain, harbours a high level of diversity and endemism, as well as many different types of landscapes and habitats. The region is also unique in terms of its historical, cultural, and linguistic heritage. Historically, the Caucasus is recognized as the region between the Black and Caspian Seas, yet the ecoregional boundaries are slightly different. As an ecoregion (a geographical unit with characteristic fauna, flora, and ecosystems), the Caucasus extends from the North Caucasian plains (Russia) and includes territories in Georgia, Armenia, Azerbaijan, and parts of Turkey and the Iranian uplands (Fig. 1) (TARKHNISHVILI 2014).

The prominent features of this region are two parallel mountain ranges - the Greater Caucasus and the Lesser Caucasus. The geological history of the region is essential for understanding its current biodiversity. POPOV et al. (2004) describe in detail the geologic formation of the Caucasus. Accordingly, there is no evidence referring to the region before the Cenozoic. However, some signs of Mesozoic life have been found in the territory of modern Georgia, e.g. the footprints of dinosaurs (GABUNIA et al. 1998).

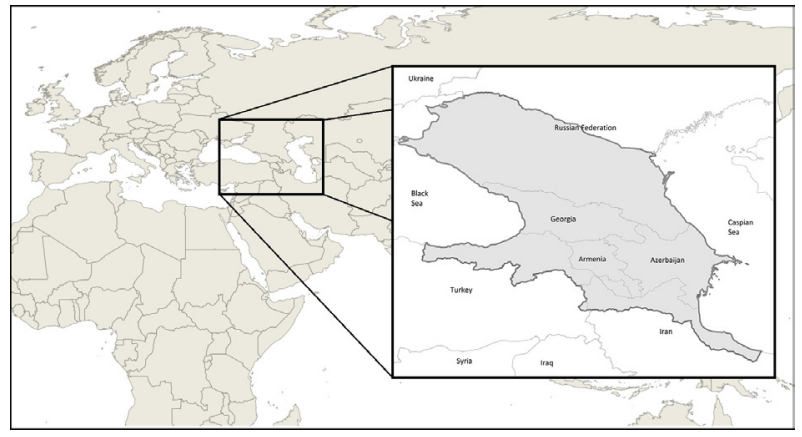

Fig. 1. The boundary of the Caucasus ecoregion.

The region, as we know it now, was formed by the end of the Pleistocene ca. 2.4 MY BP (ang. million years before present). The Lesser Caucasus began to uplift in the Early Miocene, while the Greater Caucasus emerged in the Middle Miocene (PoPOV et al. 2004); both mountain ranges are still uplifting. The Greater Caucasus remained an island in the Paratethys for several millions of years, while the Lesser Caucasus was in contact with other land massifs, mostly Asia Minor and Iranian. Hence, the colonization of the Caucasus by different species was influenced by spatio-temporal peculiarities of the geological history of the region. Such a complicated and dynamic geological history is the most common cause of the high richness in diverse species and endemism of this area. These features justify its sta-

Key words: biodiversity hotspots, Caucasus, glacial refugium, sweet chestnut

*This article was done with the financial support of the National Science Centre (Reconstruction of the evolutionary history of the Caucasian forests: comparative phylogeography of six forest tree species - Project SONATA-BIS: 2017/26/E/ NZ8/01049). 
tus as the biodiversity hotspot (Thompson 2005).

The concept of hotspots of biodiversity was originally developed by Norman Myers (MYERS 1988, 1990) and substantially revised and expanded by MYERs et al. (2000) and MitTERMEIER et al. (2011). According to the original definition, the region must have at least 1,500 endemics vascular plants to be classified as a hotspot. Another important criterion is a high degree of threat to species survival: lost of at least $70 \%$ of the original vegetation (MITTERMEIER et al. 2011). The Caucasus is one of the 36 biodiversity hotspots of global conservation importance, alongside with New Zealand, Madagascar, and the Mediterranean. Hotspots once covered $15.9 \%$ of the Earth's surface, the vegetation in these areas has since been reduced through human activities to $2.3 \%$. Overall, these precious regions contain more than half of the world's plant species $(152,000$ species) and even more of its vertebrates $(77 \%$ or 22939 species) (MITTERMEIER et al. 2011).

In terms of vascular plants, 6,400 species have been found in the Caucasus area, and more than 1,600 of them are endemic (e.g. Iris iberica Hoff. ssp. iberica; Fritillaria caucasica Adams; Gymnospermium smirnowii Trautv.; Thymus tiflisiensis Klok. \& Shost.; Papaver oreophilum Rupr.; Betula megrelica Sosn). Besides, 17 endemic genera are present there (GAGNIDZE et al., 2002). Furthermore, the region is a place of origin and domestication of many plants. For example, the domestication of the grapevine during the Neolithic Age occurred in the area of modern Georgia (IMAZIO et al. 2013). In 2017 , in pottery excavated from the archaeological sites of Gadachrili Gora and Shulaveris Gora, near Tbilisi, the presence of characteristic grapevine remnants dating back to $6,000-5,800 \mathrm{BC}$ has been documented. Georgian people still use similar traditional pottery, named Kvevri, for fermentation, ageing, and storage of wine. From the territory of modern Georgia, viniculture spread to Europe (MCGOVERN et al. 2017).

The Colchis lowlands in the West Georgia and Hyrcanian forests in Iran make the Caucasus even more unique. In those forests, we may still observe species that represent remnants of the ancient ArctoTertiary geoflora. The species of this flora predominated in the Northern Hemisphere during the Tertiary period and disappeared when the global climate cooled down (65$15 \mathrm{mln}$ YB). There are only a few locations worldwide where the remnants of Tertiary flora persist to this day (MiLNE and AB-
BOTT 2002). The relic tertiary species in the Caucasus include the Caucasian wingnut (Pterocarya fraxinifolia (Lam.) Spach), Persian ironwood (Parrotia persica (DC.), Caucasian zelkova (Zelkova carpinifolia (Pall.) Dippel), and Colchis holly-tree (Ilex colchica Pojark.) (NAKHUTSRISHVILI et al. 2015).

\section{GEORGIAN FORESTS: THREATS AND CONSERVATION}

Georgia is located in the Central Caucasus and covers only one-seventh of this region. Nevertheless, almost all the landscapes and biomes of the Caucasus region can be found here, including semi-deserts, rangelands, and arid and semi-arid Mediterranean-like landscapes (Georgian Biodiversity Database; www.biodiversity-georgia.net/). However, the forest is the primary type of vegetation in Georgia, covering $36.7 \%$ of the country (Fig. 2). The prominent forest species are Fagus orientalis Lipsky (oriental beech, $51 \%$ of the total forest coverage), Abies nordmanniana (Steven) Spach (Caucasian fir, 8.5\%), Quercus species (e.g. Quercus petraea subsp. iberica (Steven ex M.Bieb.) Krassiln., 10.5\%), Picea orientalis (L.) Peterm. (Caucasian spruce, 6.3\%) or Castanea sativa Mill. (sweet chestnut, 2.1\%) (NAKHUTSRISHVILI 2013). The vast majority of the forest ecosystems are in the mountains, where about 400 different species of trees and shrubs have been identified (PATARKALASHVILI 2017).

Currently, in Georgia there are 14 Strict Nature Reserves, 12 National Parks, 20 Managed Nature Reserves, 40 Natural Monuments, two Ramsar sites, and one Protected Landscape. These territories amount to $9.29 \%$ of the country (protectedplanet.net).

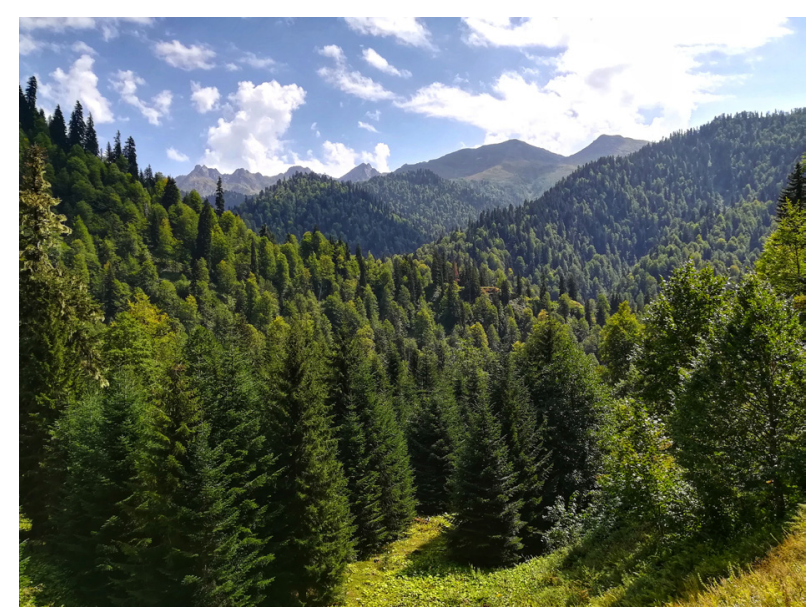

Fig. 2. Dark-coniferous forest dominated by the Caucasian spruce and Nordmann fir, Lebarde, Western Georgia, approx. 1530 m a.s.1. 
One of the most impressive examples is the Lagodekhi Protected Area in Eastern Georgia that has been protected since 1912. Eminent Polish explorer and scientist Ludwik Młokosiewicz (1831-1909) contributed enormously to the development of the reserve. $\mathrm{He}$ was astonished by the beauty of the Georgian nature and dedicated his entire life to exploration of the Caucasus mountains. Forest communities cover $73 \%$ of the Lagodekhi Protected Area. The territory extends from 590 to $3500 \mathrm{~m}$ a.s.1., including several gorges. Natural views of Lagodekhi include deciduous forest, waterfalls, rivers, lakes, and alpine meadows where eagles, bearded, and cinereous vultures fly over the tops of the mountains.

The variety in relief (various slopes with different exposition and inclination) and the accompanying variations in climate create complex physical and geographical conditions. This peculiarity is thought to be a primary driver for the diversity of species in the region, including narrow geographical endemics. In this area grow 121 endemic species of the Caucasian flora, of which nine are endemic to Georgia (seven from Lagodekhi itself) (www.apa.gov.ge). For example, peony is a local species endemic to the Caucasus mountains (Paeonia daurica subsp. mlocosewitschii (Lomakin) D.Y.Hong). Other local endemics include species of snowdrop (Galanthus lagodechianus Kem.Nath.), Gymnospermium genus (Gymnospermium smirnovii (Trautv.) Takht.), and primrose (Primula juliae Kusn.). Another endemic species that bears the name of the Polish naturalist is the grouse (Lyrurus mlokosiewiczi Taczanowski 1875). Forest ecosystems in Georgia have been profoundly affected by intense anthropogenic pressure. The country experienced a political and economic crisis throughout the 1990s. Subsequently, due to a lack of resources, people began to cut and export timber from the area illegally. Current economic and political situations are much better, but still, nature conservation is limited. Poaching and overgrazing remain a major concern in forest ecosystems. In Georgia, forests have been immensely affected by fragmentation, degradation and overexploitation. Furthermore, soil pollution and waste management are important challenges. According to the World Bank environmental analysis of Georgia (2015), the lack of compliance with the land use regulations and hydrological and environmental standards significantly worsens the effects of human activity. These factors and the ongoing climate changes accelerate the loss of biodiversity threatening the persistence of many species in Georgia. Through- out the past decades, illegal cuttings resulting from the uncontrolled export of timber, overwhelming grazing, and absence of forest management have worsened the situation, specifically for tree species. According to the Red Book of Georgia (1982), there are 150 endangered plant species, of which one third are woody species. Among them, there are several endemic tree species (e.g. Mingrelian birch (Betula megrelica Sosn.), Caucasian birch (Betula medwediewii Regel), and Berberis iberica Stev. \& Fisch. ex DC.). One of the examples of threatened tree species valuable for forest ecosystems is sweet chestnut. The tree is distributed throughout the Caucasus; however, it mostly occurs in Georgian forests. Here the tree is a significant part of the forest ecosystems. Invasive species pose another significant threat to the region, especially invasive parasites. Dead masses of Colchis box trees (Buxus colchica Pokark) exemplify the devastating impact of biological invasions. An invasive fungal pathogen (Calonectria pseudonaviculata) causing dangerous disease box blight with parasitic insect (box tree moth, Cydalima perspectalis (Walker)), introduced during the Winter Olympics in Sochi in 2014 has significantly affected the box tree stands in Georgia. There is no reliable information, but according to various sources, 30-90\% of the box tree stands are lost; scientists describe the current situation as a pandemic (PATARKalashvili 2017, BRAs et al. 2019).

\section{SWEET CHESTNUT TREE IN GEORGIA}

European sweet chestnut (edible chestnut, Castanea sativa Mill.) is a long-lived, warm-tolerant deciduous tree species that attains a height of 20-35 m. It grows extraordinarily shaped seeds resembling hedgehogs. The fruit of the tree is both delicious and nutritious. The species requires a mild and moist climate. Sweet chestnut is a self-incompatible tree species living to the age of 500 years. Cultivations of the sweet chestnut have a long history. It was considered that the primary driving factor for its cultivation was food production in Roman times. However, scientists have questioned this hypothesis, suggesting that the species was firstly cultivated to obtain timber and charcoal (CONEDERA et al. 2004).

Commonly, sweet chestnut is associated with the countries of the Mediterranean Basin, where it is widely cultivated. However, sweet chestnut grows naturally and is also cultivated in Asia Minor and in the Caucasus (Fig. 3). Castanea sativa is one of the most valuable species of Georgian forests. Sweet chestnut grows mainly in the west- 


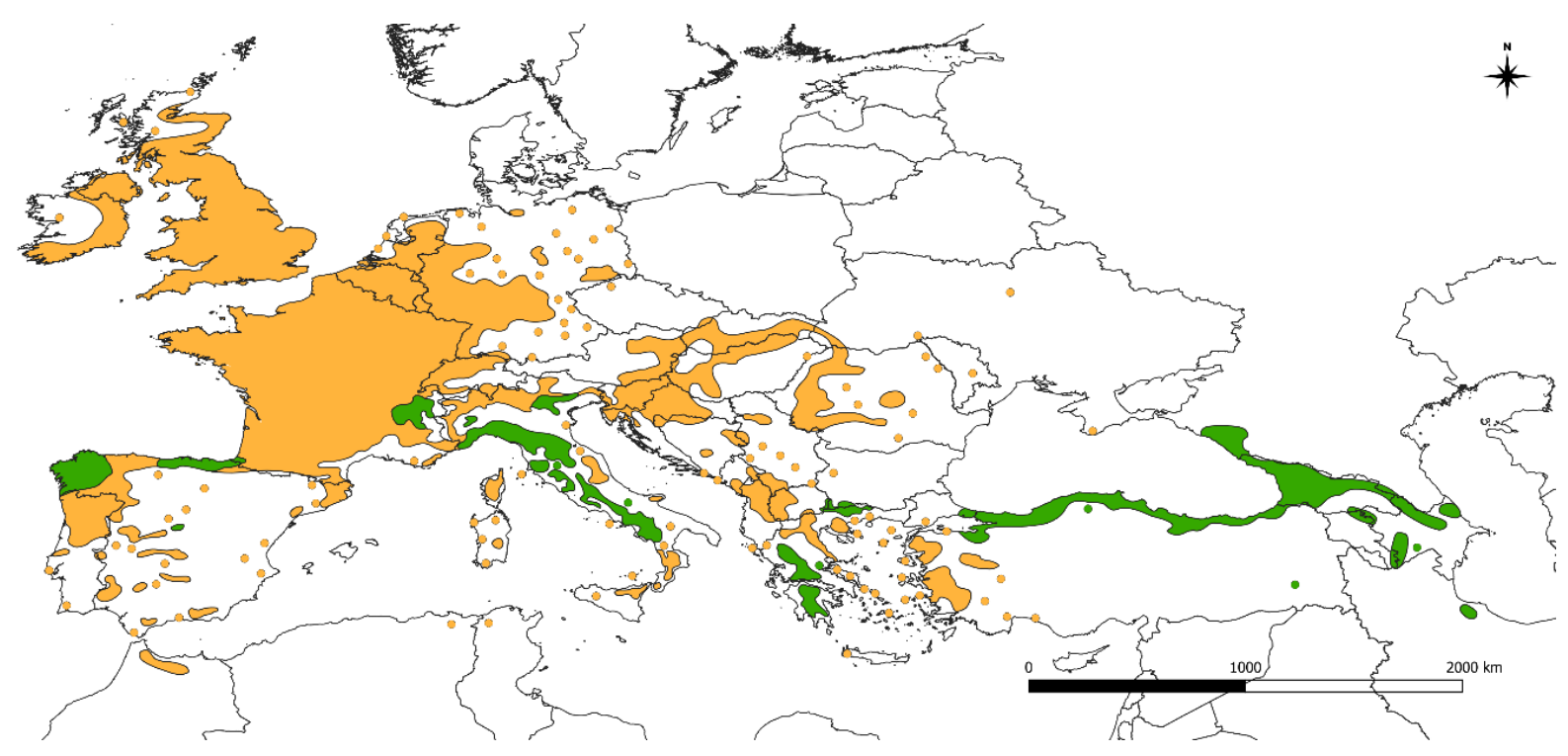

Fig. 3. Natural (green) and cultivated (orange) range of Castanea sativa.

ern part of the country, but the tree is also found in the eastern region. At an altitude of 500-1000 $\mathrm{m}$ a.s.1 in Western Georgia, chestnut forms pure stands. Below $500 \mathrm{~m}$ a.s.1, the species can be found with Georgian oak (Quercus iberica M.Bieb.) and European ash (Fraxinus excelsior L.), while above 1000-1200 $\mathrm{m}$ it grows with the Caucasian fir (Abies nordmanniana).

The sweet chestnut has been a part of the natural ecosystem since the first appearance of humans in the Caucasus. Apart from immense ecological and economic value, the species of this region also have significant aesthetic importance. Georgian tribes, and especially Colchians, were skilled sailors and shipbuilders who used the chestnut tree as a material for shipbuilding. The tree was called "the golden tree" for its useful and valuable properties. People preferred chestnut timber for the construction of houses and other structures. Windows, doors, and fences are also made with the chestnut tree (NAIBA et al. 2017). Additionally, people have been using chestnut honey for a long time.

According to the International Union for Conservation of Nature (IUCN), C. sativa has been assessed with the Least Concern risk status. This designation certainly does not reflect the alarming situation of the species' natural population in the Caucasus. Sweet chestnut is an endangered species in Georgia and Azerbaijan (The Red Book of Georgia, Red List Committee Azerbaijan). The situation in other countries of the Caucasus ecoregion is probably bad as well; how- ever, there is a lack of official assessments. For example, the sweet chestnut population in the Hyrcanian forests in Iran has also been sharply declining (GHEZI et al. 2010). Several factors are responsible for this situation. Drought and human activity (mainly illegal cutting) increase susceptibility of sweet chestnut to different fungal parasites, including chestnut blight (Cryphonectria parasitica (Murrill) Barr), leaf-spot disease ( $C y$ lindrosporium castaneae (Lév.) Krenner) and ink-disease caused by the pathogenic genus Phytophthora ( $P$. cambivora (Petri) Buisman and $P$. cinnamomic Rands). Among them, the most dangerous is aggressive chestnut blight fungus, which damages the phloem, causes excessive drying of the branches and subsequent death of the tree (Fig. 4).

Chestnut blight was first noticed in 1904 when it caused illness in American chestnut trees (Castanea dentata (Marsh.) Borkh.) in New York. Since then, the fungus has almost completely wiped out this entire species. In Georgia, reports about the disease appeared first in 1938 (SHAVLIASHVILI 1953). However, the first descriptions of symptoms similar to chestnut blight can be found in the literature long before the parasite was associated with the disease (TAVADZE et al. 2013). Cryphonectria parasitica was introduced to Europe from its native range in China and Japan in the 1930s. As there are today two distinct gene pools of this species present in Europe, it was probably introduced independently two times in this area (PROSPERO et al. 2013). Interestingly, Georgian populations of chestnut blight are 


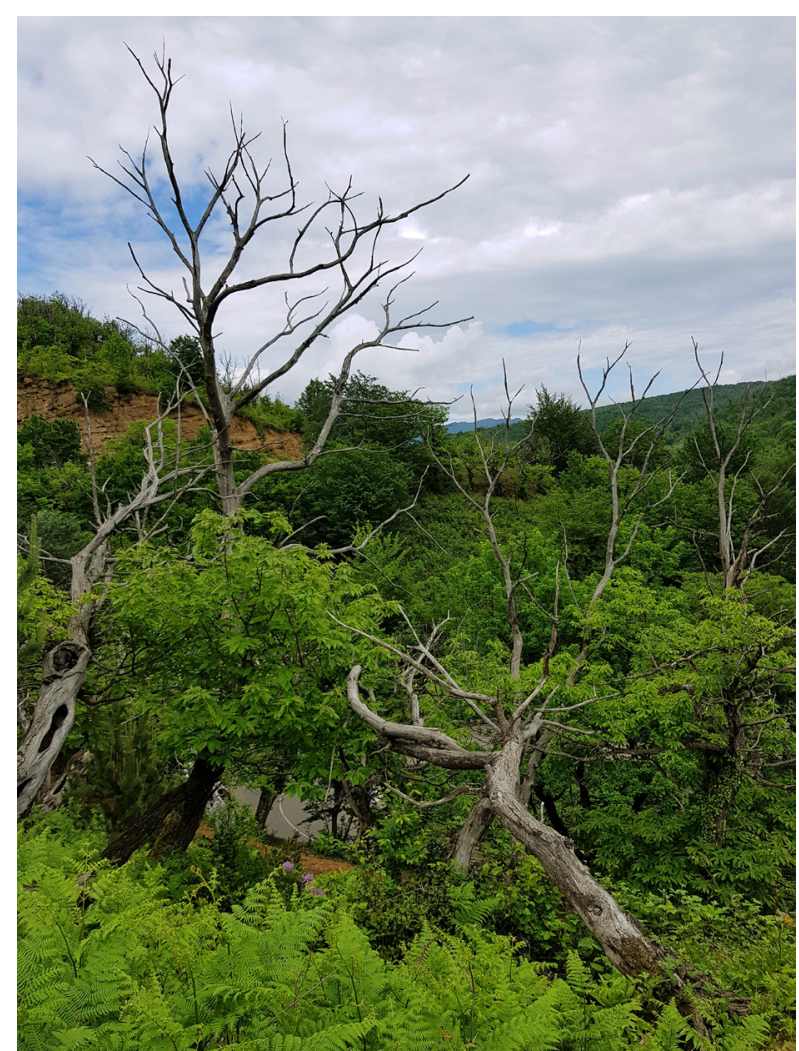

Fig. 4. Dried sweet chestnut trees possibly because of Cryphonectria parasitica near Tkibuli, Western Georgia.

characterized by higher degree of genetic diversity in comparison to the European gene pool (PROSPERO et al. 2013). There are two haplotypes unique for Georgia, presumably formed locally through the sexual recombination. The genotypic diversity of the studied chestnut blight populations was lower in the eastern part of the country compared to the western part. Hence in comparison to the natural range, a lower genetic diversity is noted in the invasive regions, it is possible that the eastern part of the Caucasus was colonized recently by the parasite, especially as it was first detected in Azerbaijan in 2004, and from there it could spread to eastern Georgia.

Even though the disease was reported for the first time almost a century ago in Georgia, scientific surveys and assessments have appeared only in the past twenty years. TAVADZE et al. (2013) published a paper concerning the pathological status of the chestnut forests in Georgia. In 20102011, with the support of the Swiss National Science Foundation and Georgian Ministry of Environmental Defence, the authors investigated the chestnut forest's status in Georgia. According to the report, in the Tkibuli district (western part of the country) in 2010 , almost $40 \%$ of the trees were either dying or already dead. Dead or dying trees constituted $70 \%$ of all recorded specimens in Keda and $60 \%$ in the Chiatura region (Western Georgia). In another study, the authors noted in the Keda municipality the extremely bad situation of the chestnut - out of 164 trees, only 25 were healthy; sprouts and seedlings were rare. Moreover, infected trees were not being cut and removed, even though this should be a routine management practice in the case of an infected individual (DUMBADZE et al. 2018).

In 2018, a local group of scientists (Ministry of Environmental Protection and Agriculture of Georgia), in partnership with the Austrian Development Cooperation and the Caucasus Environmental NGO Network (CENN), launched an initiative aimed at monitoring the risks faced by $C$. sativa in Georgia (CECH and $\mathrm{HoCH}$ 2018). The scientists reviewed all available information relevant to sweet chestnut blight, currently considered as the most critical factor in the massive decline of the species. At the end of the assessment, the authors gave their recommendations for the restoration of $C$. sativa forest stands ( $\mathrm{CECH}$ and $\mathrm{HOCH} 2018$ ). These recommendations included protection and monitoring of noninfected stands of sweet chestnut and avoiding trade with chestnut plants. The authors also pointed out the importance of the removal of dying or already dead trees to prevent the subsequent spreading of the disease. Additionally, they advised on the importance of international and national collaboration for effective species restoration ( $\mathrm{CECH}$ and $\mathrm{HOCH} 2018)$.

\section{PERSPECTIVES}

For species conservation, it is essential to identify populations that are important for preservation. For this purpose, genetic studies give scientists the ability to point out the populations that are most important in terms of genetic diversity (PETIT et al. 1998). For the Caucasus, and specifically for Georgia, the phylogeographic investigations are essential for tree species conservation because they may provide the data about the geographic distribution of the genetic variability. Glacial refugia have had an unprecedented impact on the current spatial patterns of genetic diversity and differentiation (HEwITT 2000). The Caucasus is considered to be a refugial area during the Last Glaciation (LGM). Paleoclimatic models suggest that there were six regions of West Asia where forest vegetation could have survived the LGM (TARKHNISHVILI et al. 2012); 
some of them were likely located in the Colchis in West Georgia.

The glacial refugia for the sweet chestnut are not fully understood and remains a matter of debate among scientists. In their novel approach based on comprehensive paleobotanical data, KREBS et al. (2019) were able to suggest possible refugial areas for the sweet chestnut. One of them was, with a high probability index, Colchis in West Georgia. Here, unlike in other suggested areas (e.g. the Italian and Iberian Peninsulas), the tree's distribution remained almost constant and wide throughout the Pleistocene. Colchis, situated northward of the Greater Caucasus and eastward of the Black Sea, could have been an excellent place for the survival of C. sativa during the LGM. Detailed phylogeographic studies on sweet chestnut from the Caucasus have not yet been performed. However, MATTIONI et al. (2017) analysed eight populations from the region with six nuclear microsatellite markers. They indicated the conservational priority of the Georgian chestnut stand based on the high genetic diversity they observed. Yet, the evolutionary history of sweet chestnut in the Caucasus remains to be discovered. The conservation program, which is highly needed to prevent the decline of the sweet chestnut in Georgia, would likely benefit largely from that knowledge. Currently, the species is not included in any conservation action in Georgia.

The Caucasus is the region of global importance. Georgia represents a relatively small part of the ecoregion. However, it contains the most significant part of the Caucasian forests. Facing threats mainly induced by human activities, Georgian forests lack active management and real protection. Future changes of the global climate are predicted to fragment the forests, of which many may be lost in the Caucasus, and specifically in Georgia. This poses a threat to long-term persistence of many plant species, including trees. Having the genetic resources of the species mapped, conservationists already know how to allocate the conservation efforts. Which populations are of vital importance for conservation in the first place? Where to collect seeds for plantings or ex-situ collections? These are only basic conservation applications that will benefit from recognition of the genetic diversity and its spatial patterns in sweet chestnut and other species present in the Caucasus. Moreover, the more genetic diversity populations harbour, the higher the chances of their survival in a rapidly changing environment.

\section{Summary}

The Caucasus ecoregion is located between the Black and the Caspian Sea and extends from southern Russia, throughout Turkey, Georgia, Armenia, Azerbaijan up to Iran. The prominent feature of the region is high biodiversity and endemism. The outstanding biological richness made the Caucasus one of the 36 global hotspots of biodiversity. The Caucasian forest is concentrated mainly in Georgia, where the most diverse forest ecosystems are found. In the Colchis forest, Tertiary relicts are present and this area formed glacial refugium for flora and fauna. However, the region and its wildlife are now under threat. Uncontrolled logging, urban and agricultural development, and climate changes bring about the great risk for many species and unique plant assemblages. The massive decline of Castanea sativa (sweet chestnut) exemplifies the problems of the alien parasite invasions and ineffective forest management and nature conservation. Biodiversity of the Caucasus is being lost at an alarming rate that calls for urgent action and intensification of investigations aiming at better understanding of the evolutionary history of the region.

\section{REFERENCES}

Bras A., Avtzis D. N., Kenis M., Li H., VÉtek G., Bernard A., Courtin C., Rousselet J., Roques A., Auger-RozenBerG M. A., 2019. A complex invasion story underlies the fast spread of the invasive box tree moth (Cydalima perspectalis) across Europe. J. Pest Sci. 92, 1187-1202.

CECH L. T., HOCH G., 2018. The assessment of edible chestnut forest stands in West Georgia and - recommendations for their restoration. http://environment.cenn.org/app/uploads/2018/08/CENN_Chestnut_Recomendations_180808_ENG.pdf).

Conedera M., Krebs P., Tinner W., Pradella M., TORRIANI D., 2004. The cultivation of Castanea sativa (Mill.) in Europe, from its origin to its diffusion on a continental scale. Vegetat. History Archaeobot. 13, 161-179.

Dumbadze G., Temel G., Vasadze T., Lomtatidze N., CJAKHVADZE K., 2018. Intensity of Chestnut drying and natural restoration of forest in Keda municipality (Ajara, Georgia). Int. J. Ecosyst. Ecol. Sci. 8, 347-352.

Gabunia K. L., Mchedlidze G., CHKhikvadze M. V., LUCAS G. S., 1998. Jurassic sauropod dinosaur from the Republic of Georgia. J. Vertebrate Paleontol. 18, 233-236.

GagnidZe R., GviniashVili T. S., SHetekauri SH., MARGALITADZE N., 2002. Endemic genera of the Caucasian flora. Feddes Repertorium: Zeitschrift für Botanische Taxonomie und Geobotanik 113, 616-630.

GHEZI E., KHODAPARAST S. A., ZARE R., 2010. Distribution and severity of damage by Cryphonectria parasitica in the chestnut stands in Guilan province. Forest Pathol. 40, 450-457.

HEwITT G., 2000. The genetic legacy of the Quaternary ice ages. Nature 405, 907-913.

IMAZIO S., MAGHRADZE D., DE LORENZIS G., BACILIERI R., LAUCOU V., THIS P., ScIENZA A., FAILIA O., 2013 From the cradle of grapevine domestication: molecular overview and description of Georgian grapevine (Vitis vinifera L.) germplasm. Tree Genet. Genomes 9, 641-658.

Krebs P., Pezzatti B., G. B., BefFA G., Tinner W., CONEDERA W., 2019. Revising the sweet chestnut (Castanea sativa Mill.) refugia history 
of the last glacial period with extended pollen and macrofossil evidence. Quat. Sci. Rev. 206, 111-128.

Mattioni C., Martin M. A., Chiocchini F., CheruBini M., Gaudet M., POllegioni P., VelichKOV I., JARMAN R., CHAMBERS F. M., PAUle L., Damian V. L., Ghiță C. C., Villani F., 2017. Landscape genetics structure of European sweet chestnut (Castanea sativa Mill): indications for conservation priorities. Tree Genet. Genomes 12, 39.

MCGOVERN P., JALABADZE M., BATIUK S., CALlahan P. M., SMITH E. K., 2017. Early Neolithic wine of Georgia in the South Caucasus. Proc. Natl. Acad. Sci. USA 114, E10309-E10318.

Milne R. I., АвBOtT R. J., 2002. The origin and evolution of Tertiary relict floras. Academic Press 38, 281-314.

MitTermeier R. A., TURner W. R.., LARSEN F. W., BROOKS T. M., GASCON C., 2011. Global biodiversity conservation: The critical role of hotspots. [In:] Biodiversity Hotspots: Distribution and Protection of Conservation Priority Areas. ZACHOS F. E., HABEL J. C. (eds.). Springer, 3-22.

MYERS N., 1988. Threatened biotas: "Hot spots" in tropical forests. Environmentalist 8, 187-208.

MYERS N., 1990. The biodiversity challenge: Expanded hot-spots analysis. Environmentalist 10, 243-256.

Myers N., MitTermeier R. A., MitTermeier C. G., DA Fonseca G. A., KenT J., 2000. Biodiversity hotspots for conservation priorities. Nature 403, 853-858.

Naiba P. M., Valida M. A., Ketevan B., ZaAl K., MANANA K., INESA M., Shalva S., DaVID T., NAREL Y. P. Z., RAINER W. B., 2017. Castanea sativa Mill. Fagaceae. [In:] Ethnobotany of the Caucasus. BuSSMANN R. W. (Ed.). Springer International Publishing, 177-182.

NAKHUTSRISHVILI G., 2013. The Vegetation of Georgia (South Caucasus). Springer Berlin Heidelberg.

NAKHUTSRISHVILI G., ZAZANASHVILI N., BATSATSASHVILI K., Montalvo C. S., 2015. Colchic and
Hyrcanian forests of the Caucasus: similarities, differences and conservation status. Flora Mediterranea 25, 185-192.

PATARKALASHVILI T., 2017. Forest biodiversity of Georgia and endangered plant species. Ann. Agrarian Sci. 15, 349-351.

PetiT R. J., El MousadiK A., Pons O., 1998. Identifying populations for conservation on the basis of genetic markers. Conserv. Biol. 12, 844-855.

Popov V. S., Rögl F., Rozanov A. Y., SteiningeR F. F., Shcherba I. G., Kovac M., 2004. Lithologipetitcal-paleogeographic maps of Paratethys: 10 maps late Eocene to Pliocene. Stuttgart.

Prospero S., Lutz A., TAvadze B., SupatashviLI A., RIGLing D., 2013. Discovery of a new gene pool and a high genetic diversity of the chestnut blight fungus Cryphonectria parasitica in Caucasian Georgia. Infect. Genet. Evolut. 20, 131-139.

SHAVLIASHVILI I. A., 1953. The causes of drying sweet chestnut in Georgia. Dissertation, Tbilisi (in Russian).

TAvadze B. L., Supatashvili A. Sh., Rigling D., Sotirovski K., Mamukashvili T. S. I., Chitia S. T., 2013. Pathological status of chestnut stands in Georgia. Ann. Agrar. Sci. 11, 104107.

TARKHNISHVILI D., 2014. Historical biogeography of the Caucasus. NOVA Science Publishers.

TARKHNishVILI D., GaVashelishVILI A., MumladZE L., 2012. Palaeoclimatic models help to understand the current distribution of Caucasian forest species. Biol. J. Linnean Soc. 105, 231-248.

THOMPSON J. D., 2005. Plant evolution in the Mediterranean. Oxford University Press on Demand. 
Kosmos Vol. 70, 1, 19-26, 2021

\section{BERIKa BERIDZE, Monika DERING}

Zakład Biogeografii i Systematyki, Instytut Dendrologii PAN, Parkowa 5, 62-035, Kórnik, E-mail:berikaberidze@man.poznan.pl, mdering@man.poznan.pl

\section{PROBLEMY I ZAGROŻENIA EKOSYSTEMÓW LEŚNYCH KAUKAZU NA PRZYKŁADZIE CASTANEA SATIVA}

\section{Streszczenie}

Ulokowany między Morzem Czarnym i Kaspijskim, kaukaski ekoregion obejmuje obszary leżące na południu Rosji, Turcję, Gruzję, Armenię, Azerbejdżan i Iran. Wyjątkowość biologiczna tego obszaru polega na wysokiej koncentracji bioróżnorodności i endemizmu. Z tego powodu Kaukaz jest jednym z 36 globalnych gorących centrów różnorodności biologicznej (ang. biodiversity hotspots). Najbardziej różnorodne ekosystemy leśne występują w Gruzji. W lasach kolchidzkich na wschodzie Gruzji do dzisiaj rosną relikty trzeciorzędowe, a w okresie ostatniego zlodowacenia obszar ten stanowił refugium dla europejskiej flory i fauny. Niestety, to ewolucyjne bogactwo jest poważnie zagrożone. Rabunkowa gospodarka leśna, urbanizacja i rozwój rolnictwa niosa ryzyko dla gatunków i unikatowych zbiorowisk roślinnych Gruzji i Kaukazu. Masowe zamieranie kasztana jadalnego (Castanea sativa) w gruzińskich lasach to wynik inwazji pasożytów zawleczonych przez człowieka oraz braku racjonalnej gospodarki leśnej i efektywnej ochrony. Kaukaz traci swoją bioróżnorodność w szybkim tempie, co wymaga nie tylko podjęcia zdecydowanych i natychmiastowych działań w celu ochrony tego wyjątkowego obszaru, ale i podjęcia szerszych badań by zrozumieć ewolucyjną historię regionu.

Słowa kluczowe: bioróżnorodność, kasztanowiec, Kaukaz, refugium lodowcowe 